\title{
THE REGULATORY EFFECT OF PUBLIC EDUCATION EXPENDITURES ON INCOME DISTRIBUTION
}

\author{
Müzeyyen Özlem ÇETíN ${ }^{1}$
}

\begin{abstract}
The education system is one of the important factor which effects to development level of a country. Beside the quality of educational system, equity in access to the education is the important topic too. Equity in access to education can help to equitable income distribution, to between different income groups who live in a country.

It is stated that, nowadays inequalities on income distribution have reached very serious dimensions. It is believed that, education expenditures, which make by government, can be important tool to reduce the inequality especially inside the countries.

The aim of this study is to evaluate to general government education expenditures/Gross Domestic Product (GDP) ratios at the member countries of Organisation for Economic Co-operation and Development (OECD) where income relatively equitable distributes.

The effects of education level on a country's economy are evaluated in the first chapter of the study. It is stated that, the quality education systems have positive effects to the development levels of the countries. Information is also provided about the dimensions of income inequality in the first chapter. Additionally it is mentioned that, providing equality in access to education has probable positive effects on the income inequality.

Numerical values about general government education expenditures/GDP ratios in OECD countries where income distribution relatively more equitable (Gini coefficients are used in the measurement of income distribution in this study), are included in the second chapter. OECD data are used for both variables in this study.

When the data in the study are evaluated, it can be said that the level of public education expenditures have positive effects on income distribution in general. The equitable distribution of income in a country can be due to different reasons. However it can be said that, the education services, which are provided by government, because there are more equitable access to these services, can be used as a tool for reduce the inequality when we generally evaluation.
\end{abstract}

Keywords: Income distribution, Gini coefficient, Education, Public education expenditures

JEL Code: H52, 124.

\section{Introduction}

Income inequality has increased notably especially since last quarter of 20th century. Income inequality not only increases between countries, but also increases between different income groups in the same country. Countries own income inequality is considered in this study.

Provide to equitable distribution of income between the people who live in a country; is important in point of income distribution regulatory function of fiscal policies. The policies for equitable distribution of income with fiscal policies are applied via public revenues and public expenditures.

1 Lecturer PhD, Marmara University, Vocational School of Justice, muzeyyen.ozlem@marmara.edu.tr 
The aim of this study is to evaluate the effects of public education expenditures on income distribution. The ratios of public education expenditures/GDP in the OECD countries, which have relatively more equitable income distribution, are examined in this study. The most actual accessible Gini coefficient (disposable income, post taxes and transfers) OECD data (2015 and 2016) are used in this study, for can evaluate about income distribution. General government education expenditures/GDP ratios are used for measure to public education expenditures/GDP ratios. The most actual accessible three-year OECD data (2013-2015) are examined in this study.

\section{The Relationship of Education Level with Economies of Countries}

\subsection{Education Level and Economic Development}

For a country's industrialization, necessary to be established a political infrastructure and a physical infrastructure. These prerequisites are known and tried to fulfill by economies, which want to be industrialize. But there is another prerequisite, which has an importance as much as these two prerequisites, effective for process of spread and develop of industrialization. This is fundamental and technical education level of the population (Yenal, 2017: 36).

It is seen that, this three fundamental prerequisites have existed since approximate 16th century in the European countries. In the transition from the Middle Ages to the New Ages, in the nation states, which replaced city states or principalities, the physical infrastructure was developed while the legal organization was strengthened. At the same time, important leaps were realized at education area in this period. Recently it has been accepted that, fundamental education is an important variable, which explains difference development speeds of underdevelopment countries (Yenal, 2017: 36-37).

\subsection{Education Level and Income Inequality}

Concept of income distribution means that, distribution of national income between persons or production factors. Beside to income growth, sharing of income growth between people, who live in a country, is an important subject. Income distribution is measured two ways. The first of these is functional income distribution. Functional income distribution explains that, how is shared of income which is created in a country, between wage, interest, profit and annuity groups. The second of these is personal income distribution. Personal income distribution explains that, how is shared of income, between different population groups in a country (Eğilmez \& Kumcu, 2006: 126).

The most common way to used for measurement of income distribution is the Lorenz curve, which takes account of personal income distribution, and the Gini coefficient, which based on the Lorenz curve. The Lorenz curve geometrically shows to income distribution disorder. The Gini coefficient puts forth to income distribution disorder mathematically. When the Gini coefficient approaches zero, the distribution of income is more equitable. When the Gini coefficient approaches one, the distribution of income is more inequitable. The Gini coefficient can't be bigger than one. The zero means absolute equality and there is no country in the world like this (Eğilmez, 2015: 214- 215). 
The Gini coefficient is usually between 0.25 and 0.50 in the world countries. The Gini coefficient is usually low levels in the North countries, where applied social democracy, and most of the old Socialist countries (Eğilmez, 2012).

Oxford Committee for Famine Relief (Oxfam) announced that, the wealth of the world's billionaires increased by $900 \mathrm{bn}$ dollars in the last year alone while the wealth of the poorest half of humanity, (3.8 billion people) fell by 11\% (Oxfam Briefing Paper, 2019: 28).

The income inequality has an increasing tendency in the world in general; also the level of this increase differs within the countries themselves. According to World Inequality Report 2018, while income share of the top $1 \%$ was close to $10 \%$ both in Western Europe and in the United States in 1980 , it rose to $12 \%$ in Western Europe and $20 \%$ in the United States in 2016. Meanwhile, in the United States while income share of the bottom $50 \%$ was about $20 \%$ in 1980 , it fell to $13 \%$ in 2016. While in Western Europe income share of the bottom $50 \%$ was about $24 \%$ in 1980 , it fell to 22\% in 2016 (Alvaredo, Chancel, Piketty, Saez \& Zucman, 2017: 10-12).

Acemoğlu (2003) states that, in the United States inequality and skill premium were higher than in most other countries at the end of 1970s and they increased faster than the other countries. In the United States the relative skill demand increased more than the relative skill supply. This caused wage inequalities in the United States. In addition, it is states that skill premium in Europe was not as high as in the US and this was due to the more rapid increase of skill supply in the Europe (Acemoğlu, 2003: 121, 122).

Increasing the labor force supply, with high level of skill, depends on increasing of well educated population. Skill supply can be increased with more accessible educational possibilities for everybody. Thus, the negative impact of wage inequality on income distribution can be neglected (Özalp, 2018: 86-87).

In developed countries, care is given to the access to educational services of the same quality by all students. In this way, equal opportunity is provided and income distribution is improved significantly (Altınışık \& Peker, 2008: 112).

Sahlberg (2018) states that, an education system in which equity is guarded and students are well educated can eliminate the effects of large scaled social and economic inequalities (Sahlberg, 2018: 82).

\section{The Effects of Public Education Expenditures on Income Distribution}

According to Oxfam, public expenditures have an effect to decrease to poverty and inequality. Providing services like health, education and social protection has an important role to decrease to difference between rich and poor (Oxfam Briefing Paper, 2019: 17-18).

In the OECD countries, which have lower educational resources, there are important differences to distribution of educational resources between advantaged and disadvantaged schools. Scarce resources usually concentrate to the advantaged schools. The disadvantaged schools, fall into more disadvantage condition from this reason (OECD, 2013: 107-108).

The wage inequalities lower than the other countries at the Scandinavian countries. Because they have relatively egalitarian and inclusive education systems (Piketty, 2014: 328). 
Opposite of the opinions which claiming that market mechanism increasing the quality of education, these mechanisms usually cause to decomposition of the children and schools. It is accepted that in Finland, education is a public right, which providing benefits all of the society, from preschool to adulthood. It is believed that, the public schools are the best way of providing equal of opportunities in the Finland education system (Sahlberg, 2018: 84-85).

In order to be able to speak of a true equality in education, access to schools with high returns need to be equal and, more importantly, the quality of education of all schools need to be equalized. Equity of education quality of all schools can be realized only with public investments (Milanovic, 2018: 238-239).

Table 1. Income Distribution and General Government Education Expenditures in the OECD Countries

\begin{tabular}{|l|r|r|r|r|r|}
\hline \multicolumn{3}{|c|}{$\begin{array}{c}\text { Gini Coefficient } \\
\text { (disposable income, post taxes and transfers) } \\
\text { 2015-2016 }\end{array}$} & \multicolumn{1}{c}{$\begin{array}{c}\text { General Government Education } \\
\text { Expenditures/GDP (\%) }\end{array}$} \\
\hline \multicolumn{2}{|c|}{$\mathbf{2 0 1 5}$} & \multicolumn{1}{c|}{$\mathbf{2 0 1 6}$} & \multicolumn{1}{c|}{$\mathbf{2 0 1 3}$} & \multicolumn{1}{c|}{$\mathbf{2 0 1 4}$} & \multicolumn{1}{c|}{$\mathbf{2 0 1 5}$} \\
\hline Slovak Republic & 0,251 & 0,241 & 3,96 & 4,12 & 4,23 \\
\hline Slovenia & 0,25 & 0,244 & 6,55 & 6,03 & 5,57 \\
\hline Czech Republic & 0,258 & 0,253 & 5,11 & 5,11 & 4,93 \\
\hline Iceland & 0,255 & no data & 7,52 & 7,61 & 7,45 \\
\hline Finland & 0,26 & 0,259 & 6,4 & 6,39 & 6,25 \\
\hline Norway & 0,272 & 0,262 & 4,91 & 5,13 & 5,46 \\
\hline Denmark & 0,263 & no data & 6,88 & 7,14 & 7,04 \\
\hline Belgium & 0,268 & 0,266 & 6,39 & 6,35 & 6,42 \\
\hline Sweden & 0,278 & 0,282 & 6,57 & 6,59 & 6,53 \\
\hline Austria & 0,276 & 0,284 & 5,04 & 4,97 & 4,96 \\
\hline Poland & 0,292 & 0,284 & 5,27 & 5,26 & 5,21 \\
\hline Netherlands & 0,288 & $0,285 *$ & 5,4 & 5,39 & 5,44 \\
\hline France & 0,295 & 0,291 & 5,5 & 5,51 & 5,46 \\
\hline Germany & 0,293 & no data & 4,28 & 4,24 & 4,2 \\
\hline Korea & 0,295 & no data & 5,17 & 5,22 & no data \\
\hline Switzerland & 0,296 & no data & 5,85 & 5,79 & 5,84 \\
\hline Ireland & 0,297 & no data & 4,99 & 4,83 & 3,66 \\
\hline OECD Total & $\ldots$ & 5,34 & 5,3 & 5,24 \\
\hline
\end{tabular}

Sources: OECD, Dataset: Income Distribution and Poverty, (n.d.),

OECD, Dataset: Government at a Glance - 2017 Edition, Public Finance and Economics, (n.d.).

The table is created by us using data from the above sources.

*Provisional value 
Public education expenditures in OECD countries, where income distribution is relatively equitable, are researched by considering Gini coefficients used in the measurement of personal income distribution, in this study. Gini coefficient data (after taxes and transfers), which belongs to 2015 and 2016, obtained from the OECD are used in the study. Public education expenditures are evaluated as OECD general government education expenditures / GDP ratios (2013-2015).

Table 1 shows that in a significant proportion of countries where the income distribution is relatively more balanced, the ratios of general government education expenditures to GDP are above the OECD average or close to the average. In Iceland and Denmark, where general government education expenditures/GDP ratios are about $7 \%$, the Gini coefficients are about $0,25-0,26$. In the other countries (Sweden, Belgium, Finland), where general government education expenditures/GDP ratios are high, the Gini coefficients are about 0,26-0,28.

According to Table 1, in some countries, which have the equitable income distribution, general government education expenditures/GDP rates are under the OECD average. There are the other factors, which affect the income distribution, except public education expenditures. Nevertheless, we can say that public education expenditures have positive effects on the income distribution in general.

\section{Conclusion}

Income inequality has accessed very serious dimensions since the last quarter of 20th century, especially with effects of globalization process. The income does not equitably distribute both at the different region of the world and within themselves of the countries. The public policy tools are between the solution offers, which are put forward for eliminate the income inequality. It is thought that, public expenditures and public revenues can be used as a tool for eliminate the income inequality.

In this study, the effectiveness of public education expenditures in reducing income inequality is evaluated. Gini coefficient is one of the criterions, which is used for measure the income distribution in generally. The countries under review are selected among OECD countries with a relatively lower Gini coefficient. General government education expenditures/GDP ratios in these countries are evaluated. The OECD data are used in this study.

According to the conclusion of the study is, in the countries, where the general government education expenditures/GDP ratios are above the OECD average or are close the OECD average, the income distribution is relatively more equitable. It is seen that, general government education expenditures/GDP ratios are under the OECD average in the some countries, where the income distribute relatively equitable. There are different reasons of to have equitable income distribution. Nevertheless the study aims to make a general evaluation as of the topic covered. The conclusion of this study is the education expenditures, which make by government, have positive effects on the income distribution between the people, who live in a country. 


\section{References}

Acemoğlu, D. (2003). "Cross-Country Inequality Trends", The Economic Journal. 113, pp.121-149, https://academic.oup.com/ej/article-abstract/113/485/F121/ 5079585, (16.02.2019)

Altınışık i. \& Peker H. S. (2008). “Eğitim ve Gelir Dağılımı Eşitsizliği”, KMU iiBFF Dergisi, Y. 10 S. 15, ss. 101-118, http://dergi.kmu.edu.tr/userfiles/file/aralik2008/101-118.pdf, (08.02.2019).

Alvaredo, F., Chancel L., Piketty T., Saez E. \& Zucman G. (2017). World Inequality Report 2018, https://wir2018.wid.world/files/download/wir2018-full-report-english. pdf, (01.08.2018).

Eğilmez, M. (2012). “Gelir Dağılımında Düzelme Yok”, Kendime Yazılar, http://www.mahfiegilmez. com/search?q=Gelir+e\%C5\%9Fitsizli\%C4\%9Fi, (12.02.2019).

Eğilmez, M. \& Kumcu, E. (2006). Ekonomi Politikası, 10. Baskı, İstanbul, Remzi Kitabevi.

Eğilmez, M. (2015). Makroekeonomi, 7. Baskı, İstanbul, Remzi Kitabevi.

Milanovic, B. (2018). Küresel Eşitsizlik, Küreselleşme Çağı Için Yeni Bir Yaklaşım, (Çev.) Uzbay, M. \& Pirili M., Ankara, Efil Yayınevi.

OECD, Dataset: Government at a Glance - 2017 Edition, Public Finance and Economics. (n.d.). https://stats.oecd.org/\#, (08.02.2019).

OECD, Dataset: Income Distribution and Poverty. (n.d.). https://stats.oecd.org/\#, (08.02.2019).

OECD. (2013). PISA 2012 Results: What Makes Schools Successful? Resources, Policies and Practices, (Volume IV), PISA, OECD Publishing, http://dx.doi.org/10.1787/9789264201156en, (13.02.2019).

Oxfam Briefing Paper. (2019). Public Good or Private Wealth, January 2019, https://www.oxfam. org/en/tags/inequality, (21.02.2019).

Özalp, L. F. A. (2018). "21. Yüzyılın Huzursuz Refahı: Gelir Eşitsizliğinden Fırsat Eşitsizliğine”, iktisat ve Toplum, Y. 9, S. 98, ss. 83-88.

Piketty, T. (2014). Yirmi Birinci Yüzyılda Kapital, (Çev.) Koçak, H., İstanbul, Türkiye İş Bankası Kültür Yayınları.

Sahlberg, P. (2018). Eğitimde Finlandiya Modeli, (Çev.) Mavituna, C., 4. Baskı, İstanbul, Metropolis Yayıncilık.

Yenal, O. (2017). Ulusların Zenginliği ve Uygarlığı, Eğitim Boyutu, 4. Baskı, İstanbul, İş Bankası Kültür Yayınları. 